\title{
Preparation of Cobalt Doped DSC using Spray Pyrolysis Deposition (SPD) Technique
}

\author{
M. K. Ahmad ${ }^{1, a}$ and K. Murakami ${ }^{2, b}$ \\ ${ }^{1}$ Microelectronics \& Nanotechnology-Shamsuddin Research Centre (MiNT-SRC), Faculty of \\ Electrical and Electronics Engineering \\ University Tun Hussein Onn Malaysia (UTHM), Malaysia \\ ${ }^{2}$ Research Institute of Electronics, Shizuoka University, Japan \\ aakhairul@uthm.edu.my, brskmura@ipc.shizuoka.ac.jp
}

Keywords: Titanium Dioxide, nanorods, nanoflower, Hydrothermal, Dye-sensitized Solar Cell

\begin{abstract}
Dye-Sensitized Solar Cell (DSSC) has been prepared using Cobalt doped Titanium Dioxide (TiO2). The preparation of Cobalt doped $\mathrm{TiO} 2$ were done using spray pyrolysis method. Cobalt doped $\mathrm{TiO} 2$ thin film were annealed at $500^{\circ} \mathrm{C}$ for 3 hours and the effects of Cobalt as a dopant, towards the surface morphology and structural properties have been studied. Finally, I-V measurement of DSSC was done under illumination of AM 1.5 and $100 \mathrm{~mW} / \mathrm{cm}^{2}$.
\end{abstract}

\section{Introduction:}

A nanostructured Titanium dioxide $\left(\mathrm{TiO}_{2}\right)$ thin film gives high transmittance and good refractive index in the visible region with chemical stability and good durability in environments [1]. Due to promising in optical, electrical, chemical and structural properties $\mathrm{TiO}_{2}$ thin films have been widely used for many applications such as photocatalyst [2], multilayer optical coating [3], thin film devices for solar cell [4] and also in sensor applications [5]. $\mathrm{TiO}_{2}$ films are used in many electronic applications due to their high dielectric constant [6]. Many studies have been studied, which is found that the properties of transition metal oxides can be enhanced by doping, which widens their potential applications. Many attempts have been made to modify the physical, chemical and optical properties of $\mathrm{TiO}_{2}$ thin films by doping with transition metal oxides. In this study, we have successfully prepared $\mathrm{TiO}_{2}$ thin film doped with ion Co and used in DSC application. The electrical, structural and surface morphology were all characterized in this study.

\section{Experimental}

Silicon, glass and FTO coated glass were used as substrate in this experiment. All of the substrates are cleaned with acetone and ethanol using ultrasonic cleaner. $0.3 \mathrm{~g}$ of $\mathrm{P} 25 \mathrm{TiO}_{2}$ powder was mixed with $5.5 \mathrm{ml}$ of acetic acid and then mixed with $20 \mathrm{ml}$ of $\mathrm{TiO}_{2}$ colloid solution (TAYCA TKC-302). The solution was well stir using ceramic mortar for about 5 minutes. $0.1 \mathrm{~g}$ of Cobalt Nitrate was added into the solution which acted as a dopant in the $\mathrm{TiO}_{2}$ thin film. This solution was continuously stirred for another 5minutes. For better dispersion of $\mathrm{TiO}_{2}$ solution, $30 \mathrm{ml}$ of ethanol was added into the solution. Finally, 5 drops of non-ionic surfactant (Triton X-100) was used in the solution to enhance the conductivity of $\mathrm{TiO}_{2}$ thin film.

The thin film deposition method was done using SPD method. All of the substrates were put onto $150^{\circ} \mathrm{C}$ of hot plate. The $\mathrm{TiO}_{2}$ solution was sprayed using $0.3 \mathrm{MPa}$ of gun pressure and one time sprayed contained $0.5 \mathrm{ml}$ of $\mathrm{TiO}_{2}$ solution. All of the solution was used in this preparation. The thin films were then annealed at $500^{\circ} \mathrm{C}$ for 3 hours. The $\mathrm{TiO}_{2}$ thin film was immersed in $3 \mathrm{mMol}$ concentration of $\mathrm{N} 719$ ruthenium dye for about 14 hours. 
The thickness of the film was measured using surface profiler (DEKTAK 3). The structural properties was done using X-ray Diffractometer (RINT Ultima III-Rigaku) and the surface morphology image was observed using FE-SEM (JSM-7001F JOEL). The solar cell efficiency was measured using solar simulator under 1.5AM (Bunkoh Keiki-JUSCO).

DSC was prepared using FTO coated glass and Pt coated glass as electrode and counter electrode. The dye solution was prepared at $3 \mathrm{mMol}$ which is contained of Acetonitrile, ButylAlcohol and Ruthenium Dye (N719). The electrolyte that we used called DPMM electrolyte which contained of $0.6 \mathrm{M}$ of of 1,2-Dimethyl-3-propylimidazolium iodide, $0.1 \mathrm{M}$ LiI, $0.5 \mathrm{M}$ of 4-tert-Butylpyridine, $0.1 \mathrm{M}$ of Guanidine Thiocyanate, $0.85 \mathrm{ml}$ of Acetonenitrile, $0.5 \mathrm{ml}$ of Valeronitrile and $0.05 \mathrm{M}$ of $\mathrm{I}_{2}$

\section{Result and Discussions}

The surface morphology of the film was analyzed using Field Emission Scanning Electron Microscopy (FE-SEM). The images of $\mathrm{TiO}_{2}$ thin films which doped with Co are shown in Fig.1 (a) until 1 (c). An average size of $\mathrm{TiO}_{2}$ particle can be observed in Fig.1 (a). The $\mathrm{TiO}_{2}$ thin film shown very good porosity and the pores were well organized in the $\mathrm{TiO}_{2}$ thin film. There is no Co particles can be observed at any SEM images. The sizes of the particles were about below 50nm as were shown in Fig. 1(c). The thickness of film was measured using surface profiler (DEKTAK 3) which gives $30 \mu \mathrm{m}$ of thickness.

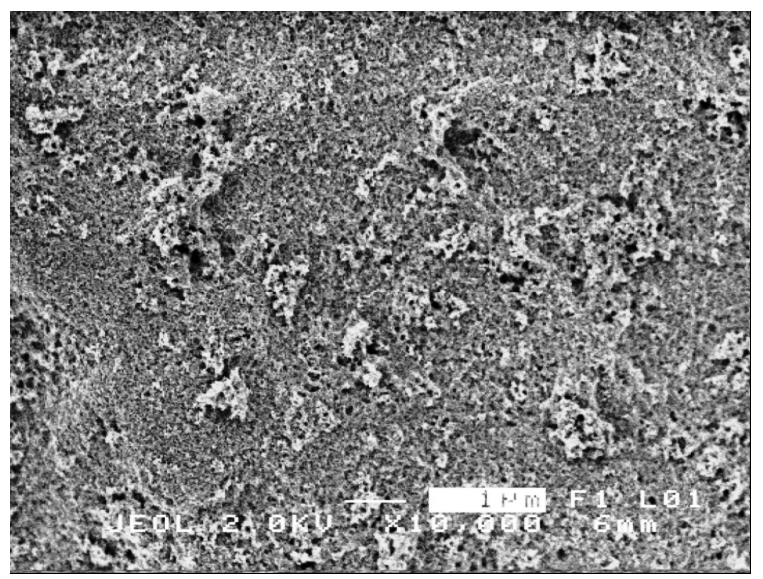

Fig. 1(a) SEM image of $\mathrm{Co}$ doped $\mathrm{TiO}_{2}$ thin film at $\mathrm{x} 10000$ magnification annealed at $500^{\circ} \mathrm{C}$

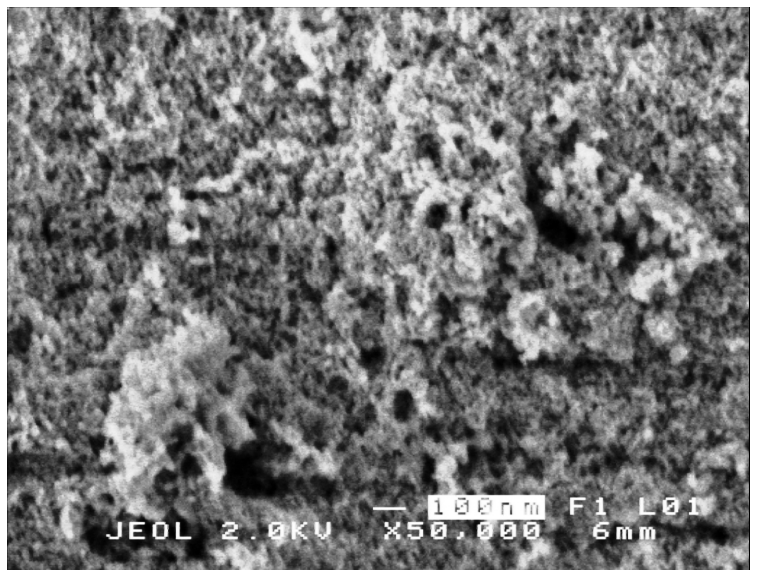

Fig. 1(b) SEM image of Co doped $\mathrm{TiO}_{2}$ thin film at x50000 magnification annealed at $500^{\circ} \mathrm{C}$ 


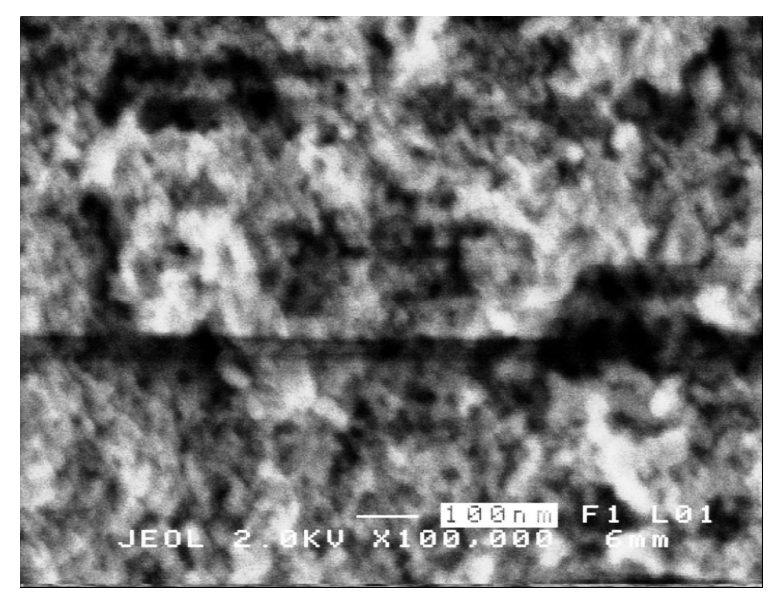

Fig. 1(c) SEM image of Co doped $\mathrm{TiO}_{2}$ thin film at x100000 magnification annealed at $500^{\circ} \mathrm{C}$

The structural properties of $\mathrm{TiO}_{2}$ thin film were carried out using Rigaku RINT Ultima III with $\mathrm{Cu}-\mathrm{K} \alpha$ radiation and $2^{\circ}$ grazing angle. Fig. 2 shows XRD pattern of $\mathrm{Co}$ doped $\mathrm{TiO}_{2}$ thin film which annealed at $500^{\circ} \mathrm{C}$ for 3 hours. From the graph, it showed that prepared $\mathrm{TiO}_{2}$ thin film was nanocrystalline and has 3 peaks which at $25.3^{\circ}, 37.9^{\circ}$ and $48.0^{\circ}$ corresponded to anatase peaks. These peaks contribute to anatase phase (101), (004) and (200) crystal planes. This result agrees with Zhang et al.[7]. All peaks observed were corresponded to JCPDS Patterns No. 21-1272. There are no additional peaks which corresponded to Co, which can be observed in the XRD pattern.

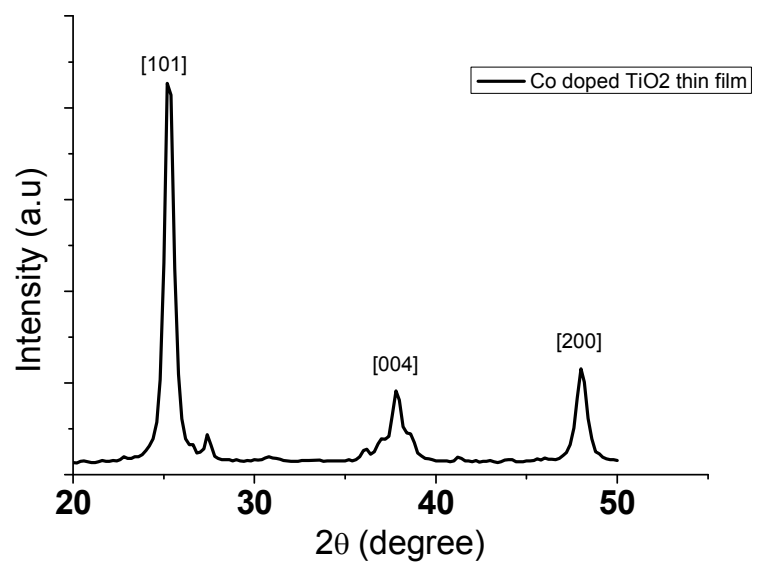

Fig. 2 XRD pattern of Co doped $\mathrm{TiO}_{2}$ thin film annealed at $500^{\circ} \mathrm{C}$

Current-voltage measurement was performed to measure the efficiency of DSC. The DSC was assembled following this configuration: $\mathrm{FTO} / \mathrm{CoTiO}_{2}+$ dye+electrolyte/Pt. From the I-V graph it shows that prepared DSC using Co doped $\mathrm{TiO}_{2}$ thin film does not gives high efficiency. It is only gives $0.20 \%$ of efficiency. It is lower compared to other researchers [8]. 


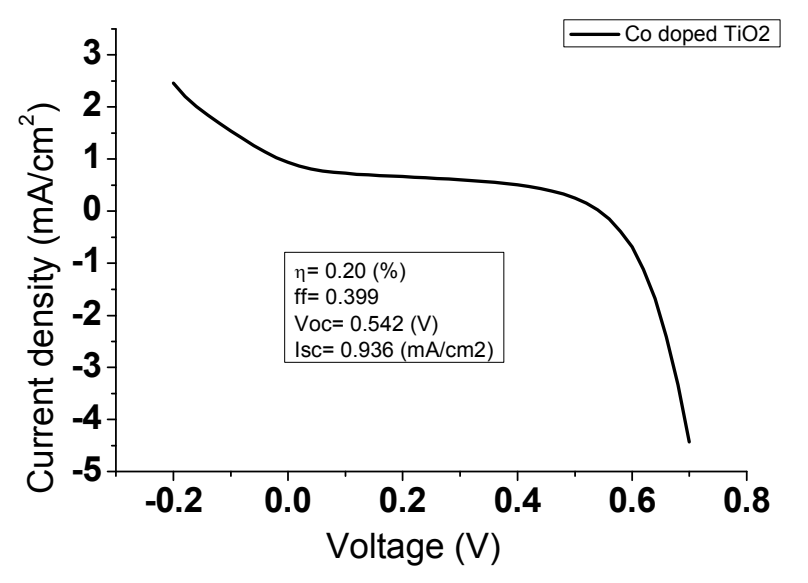

Fig. $3 \mathrm{I}-\mathrm{V}$ measurement of $\mathrm{Co}$ doped $\mathrm{TiO}_{2}$ thin

\section{Conclusion}

We had successfully prepared Co doped $\mathrm{TiO}_{2}$ thin film and used it in DSC application. From the $\mathrm{I}-\mathrm{V}$ result, Co doped $\mathrm{TiO}_{2}$ thin film DSC gave lower efficiency compared to other researcher although the surface morphology and the structural properties shows no significant differences to conventional DSC application. This included particle sizes were below 50nm and high crystallinity in anatase phase. This result was beyond difference with our earlier study about Co doped $\mathrm{TiO}_{2}$ thin film [9]. In our earlier study, we found out that $\mathrm{Co}$ doped $\mathrm{TiO}_{2}$ thin film gave high electron mobility which refer to electrical properties of Co doped $\mathrm{TiO}_{2}$ thin film. In Co doped $\mathrm{TiO}_{2}$ thin film, many excess of electrons were adsorbed at $\mathrm{TiO}_{2}$ particles, which can enhance the electron mobility. With this idea, we thought when $\mathrm{TiO}_{2}$ was doped with Co and use in DSC application; it can also enhance the efficiency of the solar cell. Unfortunately, it gave opposite result. The composition of $\mathrm{Co}, \mathrm{TiO}_{2}$, dye and electrolyte maybe become main reason. The electron mobility was increase in $\mathrm{Co}$ and $\mathrm{TiO}_{2}$ composition, but when $\mathrm{Co}, \mathrm{TiO}_{2}$ and dye solution were combined, the Co gives resistance in $\mathrm{TiO}_{2}$ thin film. It can prove by low current intensity, Isc in Fig. 3. With this, we can say that Co was not good candidate as a dopant in $\mathrm{TiO}_{2}$ based DSC application. By controlling the amount and size of the dopant itself, the solar cell efficiency should be enhanced. This is our aim study in future.

Acknowledgements. The authors would like to thank to Ministry of Education (MOE), Malaysia and Universiti Tun Hussein Onn Malaysia (UTHM) for financial support (FRGS Vot1213).

\section{References}

[1] Y. Tachibana, H. Ohsaki, A. Hayashi, A. Mitsui, Y. Hayashi, ' $\mathrm{TiO}_{2-X}$ sputter for high rate deposition of $\mathrm{TiO}_{2}$ ', Vacuum, vol. 59, (2000), pp. 836.

[2] A. Fujishima and K. Honda, 'Electrochemical Photolysis of Water at a Semiconductor Electrode', Nature, vol. 238, (1972), pp. 37.

[3] A. Dakka, J. Lafait, C. Sella, S. Berthier, M. Abd-Lefdil, J.C. Martin and M. Maaza, Optical Properties of Ag -TiO 2 Nanocermet Films Prepared by Cosputtering and Multilayer Deposition Techniques`, Appl. Opt. vol. 39, (2000), pp. 2745. 
[4] K. Hara, T. Horiguchi, T. Kinoshita, K. Sayama and H. Arakawa,'Influence of electrolytes on the photovoltaic performance of organic dye-sensitized nanocrystalline $\mathrm{TiO}_{2}$ solar cells ', Sol. Energy Mater. Sol. Cells, vol. 70, (2001), pp. 151.

[5] H. Tang, K. Prasad, R. Sanjinés and F. Lévy, 'Effects of high frequency vibration on critical Marangoni number', Sens. Actuators B 26, (1995), pp. 71.

[6] P. Alexandrov, J. Koprinarova and D. Todorov, 'Dielectric properties of $\mathrm{TiO}_{2}$-films reactively sputtered from Ti in an RF magnetron', Vacuum, vol. 47, (1996), pp. 1333.

[7] W. Zhang, W. Liu and C. Wang, 'Tribological behaviour of sol-gel TiO2 films on glass` Wear,253, (2002), pp.377.

[8] H. Kyung-Jun, S. Wang-Geun, J. Sung-Hoon, Y. Seung-Joon and L. Jae-Wook, `Analysis of adsorption properties of N719 dye molecules on nanoporous TiO2 surface for dye-sensitized solar cell', Appl. Surf. Sci., (2010).

[9] M.K. Ahmad, N.A. Rasheid, A. Zain Ahmed, S. Abdullah and M. Rusop, 'Study of Cobalt doping on the electrical and optical properties of Titanium Dioxide thin film prepared by sol-gel method' IEEE Xplore,(2008). 